\title{
Elementary School Curriculum Management in Improving Disaster Preparedness in Areas with Potential Disasters in Ngepanrejo Public Elementary School
}

\author{
Arie Supriyatno, Tawil, Holy Nikmah Imaniar \\ Universitas Muhammadiyah Magelang \\ supriyatna_56@ummgl.ac.id
}

\section{Article History}

accepted 31/08/2020

approved 22/09/2020

published 28/10/2020

\begin{abstract}
Ngepanrejo Village, Bandongan Magelang Subdistrict has hilly morphology with a slope between $20^{\circ}$ to $25^{\circ}$. This condition has the potential for landslides. This situation results in disruption of the community, including learning activities at educational institutions in the area. This study aims to determine primary school curriculum management in improving disaster preparedness in disaster-potential areas at SD Negeri Ngepanrejo. A qualitative descriptive research design with the subject of the principal, teachers, and students totaling 30 personnel. Data collection techniques by interview, observation, documentation and questionnaires. Test the validity of the data using source triangulation. The data analysis used was the Miles and Huberman model, namely data reduction, data presentation, and data verification / conclusion drawing. The results of the study concluded that 1) curriculum planning, learning tools, assessment programs and structural organization were guided by KTSP, contained the Disaster Safe Education Unit (SPAB) program, and were organized. 2) The implementation of the curriculum goes well, 3) The curriculum evaluation uses the CIPP model and is able to have a positive impact on the generation of disaster preparedness.
\end{abstract}

Keywords: Curriculum, Management, Disaster, Preparedness.

\begin{abstract}
Abstrak
Desa Ngepanrejo Kecamatan Bandongan Magelang memiliki morfologi perbukitan dengan kemiringan antara $20^{\circ} \mathrm{s} . \mathrm{d} 25^{\circ}$. Kondisi ini berpotensi bencana tanah longsor. Keadaan tersebut berakibat terganggunya masyarakat termasuk kegiatan pembelajaran di lembaga pendidikan yang ada di daerah tersebut. Penelitian ini bertujuan mengetahui manajemen kurikulum SD dalam peningkatan kesiapsiagaan bencana di daerah berpotensi bencana di SD Negeri Ngepanrejo. Rancangan penelitian deskriptif kualitatif dengan subjek kepala sekolah, guru, dan peserta didik sejumlah 30 personil. Teknik pengumpulan data dengan wawancara, observasi, dokumentasi dan angket. Uji keabsahan data menggunakan triangulasi sumber. Analisis data yang digunakan adalah model Miles dan Huberman, yaitu reduksi data, penyajian data, dan penarikan kesimpulan/verifikasi data. Hasil penelitian disimpulkan bahwa 1) perencanaan kurikulum, perangkat pembelajaran, program penilaian dan pengorganisasian strukturalnya telah berpedoman pada KTSP, memuat program Satuan Pendidikan Aman Bencana (SPAB), dan terorganisir. 2) Pelaksanaan kurikulum berjalan baik, 3) Evaluasi kurikulum menggunakan model CIPP dan mampu memberikan dampak positif terhadap generasi siaga bencana.
\end{abstract}

Kata kunci: Manajemen, Kurikulum, Kesiapsiagaan Bencana.

Social, Humanities, and Education Studies (SHEs): Conference Series https://jurnal.uns.ac.id/shes

p-ISSN 2620-9284 e-ISSN 2620-9292 


\section{PENDAHULUAN}

Wilayah Kecamatan Bandongan merupakan salah satu Kecamatan di Kabupaten Magelang yang berpotensi bencana alam yaitu tanah longsor. Hal ini dikarenakan, Kecamatan Bandongan berada pada ketinggian 431 mdpl dengan memiliki relief yang terjal, sehingga berpotensi terjadi pergerakan tanah (longsor). Hal ini sesuai dengan pernyataan BNPB (2017) bahwa penyebab utama terjadinya tanah longsor adalah adanya gravitasi yang memengaruhi suatu lereng yang curam, yaitu peningkatan kandungan air dalam lereng, terjadinya saturasi akibat hujan lebat atau gempa bumi, adanya getaran mesin atau kendaraan berat yang berlebihan, serta penyalahgunaan lahan lereng dan pemotongan lereng tanpa perhitungan. Desa Ngepanrejo memiliki morfologi berupa perbukitan relatif terjal dengan kemiringan lereng antara $20^{\circ} \mathrm{s} . \mathrm{d} 25^{\circ}$. Kondisi geografis ini menjadikan Desa Ngepanrejo sebagai daerah berpotensi terjadi bencana tanah longsor ketika curah hujan tinggi. Keadaan tersebut mengakibatkan terganggunya aktivitas masyarakat dalam berbagai sektor dan mengganggu pembelajaran di lembaga pendidikan yang ada di daerah tersebut.

Kesiapsiagaan bencana merupakan proses pembentukan aspek pengetahuan, sikap, dan keterampilan individu dalam menghadapi ancaman bencana yang meliputi tindakan pencegahan dan penanggulangan bencana. Mental individu yang diharapkan yaitu sadar bencana (mengerti dan memahami tentang bencana), siaga bencana (sikap mencegah terjadinya ancaman bencana dan kesiapan menghadapi bencana), serta tanggap bencana (memiliki keterampilan dalam menghadapi dan mengatasi bencana). Penanaman kesiapsiagaan bencana melalui pendidikan merupakan salah satu jalan yang terbaik. Karena pendidikan nasional yang bertujuan untuk membentuk karakter peserta didik yang berakhlak mulia dan bertanggung jawab cocok dijadikan sebagai media mensukseskan kesiapsiagaan bencana. Husna (2011) menjelaskan kesiapsiagaan bencana adalah segala aktivitas yang dilakukan sebelum terjadinya bencana yang bertujuan untuk mengembangkan kapasitas operasional dan memfasilitasi respon yang efektif ketika terjadi suatu bencana.

Upaya kesiapsiagaan yang dilakukan pada saat bencana mulai teridentifikasikan menurut LIPI (Febriana, dkk., 2015) antara lain: (a) pengaktifan pos-pos siaga bencana dengan segenap unsur pendukung, (b) pelatihan siaga/simulasi/gladi/teknis bagi setiap sektor penanggulangan bencana (SAR, sosial, kesehatan, prasarana dan pekerjaan umum), (c) inventarisasi sumber daya pendukung kedaruratan, (d) penyiapan dukungan dan mobilisasi sumber daya/logistik, (e) penyiapan sistem informasi dan komunikasi yang cepat dan terpadu untuk mendukung tugas kebencanaan, (f) penyiapan dan pemasangan instrumen sistem dini (early warning), (g) penyusunan rencana kontinjensi (contingency plan), dan (h) mobilisasi sumber daya (personil dan prasarana/sarana peralatan).

Sekolah Dasar sangat tepat dijadikan sebagai tempat mengembangkan pendidikan siaga bencana. Hal ini dikarenakan, pembentukan karakter siaga bencana dapat dilakukan dengan pembelajaran integratif, dimana pendidikan siaga bencana diintegrasikan dalam tiap proses pembelajaran sehingga anak-anak sejak dini sudah terbiasa bersinggungan dengan materi bencana, mereka akan mampu membuat keputusan dan berperan aktif ketika terjadi bencana alam, serta mengerti bagaimana cara menyelamatkan diri. Bahkan setelah bencana terjadi, mereka tahu apa yang dilakukan tanpa menunggu bantuan. Sejalan dengan pendapat di atas, pelatihan siaga bencana perlu dilakukan setiap tahun dan memasukan materi bencana ke dalam kurikulum (Pitang, dkk., 2019).

Untuk itu kurikulum sekolah perlu dirumuskan sesuai dengan filsafat dan cita-cita bangsa, perkembangan siswa, tuntutan dan kemajuan masyarakat. Salah satu aspek yang mempengaruhi keberhasilan kurikulum diantaranya adalah pemberdayaan dalam bidang manajemen atau pengelolaan kurikulum pada suatu lembaga pendidikan. Hal ini sesuai dengan pernyataan Defyanti, (2014) yang menyatakan bahwa ada tiga aspek 
penting dan merupakan ruhnya pada setiap kurikulum, yaitu: 1) materi pembelajaran, 2) peran guru dan kepala sekolah, serta 3) manajemen kurikulum yang dilaksanakan sekolah. Oleh karena itu, pemahaman tentang konsep dasar manajemen kurikulum merupakan hal yang penting bagi para kepala sekolah yang kemudian dijadikan sebagai modal untuk membuat keputusan dalam implementasi kurikulum yang akan dilakukan oleh guru di sekolah. Pendapat tersebut sejalan dengan pendapat Haryaningrum dkk (2017).

Perlu upaya yang lebih inovatif untuk menanamkan kesiapsiagaaan bencana yaitu dengan penerapan manajemen kurikulum SD dalam kesiapsiagaan bencana. Manajemen kurikulum ini perlu diterapkan agar peserta didik memiliki wawasan yang luas serta mendalam mengenai potensi bencana yang sering terjadi serta mampu bertindak aktif, cepat, dan tanggap dalam menghadapi bencana tersebut.

Manajemen kurikulum SD dalam peningkatan kesiapsiagaan bencana merupakan salah satu cara meminimalisir pengurangan risiko bencana dengan meningkatkan kesiapsiagaan bencana pada diri peserta didik melalui perencanaan, pelaksanaan, dan evaluasi kurikulum berbasis kesiapsiagaan bencana. Tujuan utama dari manajemen kurikulum ini adalah untuk membangun mental individu yang sadar bencana (mengerti dan memahami tentang bencana), siaga bencana (sikap mencegah terjadinya ancaman bencana dan kesiapan menghadapi bencana), serta tanggap bencana (memiliki keterampilan dalam menghadapi dan mengatasi bencana) melalui pendidikan integratif yang berlangsung saat kegiatan belajar mengajar di sekolah.

Alur mekanisme manajemen kurikulum SD dalam peningkatan kesiapsiagaan bencana adalah dengan melakukan penyusunan dan pengembangan perencanaan kurikulum yang dirancang oleh kepala sekolah, staf, guru dan tenaga kependidikan, serta stakeholders dengan menyesuaikan berbagai aspek kebutuhan berdasarkan kurikulum nasional yang berlaku serta Satuan Pendidikan Aman Bencana dan Lingkungan Hidup. Setelah dilakukan perencanaan, maka dilaksanakan implementasi atau pelaksanaan realisasi dari perencanaan yang telah disusun oleh pihak perancang untuk mencapai tujuan yang ditetapkan dengan berpegang teguh pada pedoman yang ada. Evaluasi kurikulum yang dilakukan adalah dengan melaksanakan menerapkan model evaluasi CIPP (Context, Input, Process, Product).

Manajemen kurikulum dalam peningkatan kesiapsiagaan bencana di daerah berpotensi bencana, yaitu: memberikan pemahaman yang jelas dan konkrit kepada peserta didik mengenai potensi bencana dan risikonya, serta mengajarkan kegiatan pengurangan risiko bencana atau penanggulangan bencana yang terjadi di daerahnya. Selain itu, peserta didik juga menjadi pribadi yang mandiri ketika bencana melanda di daerahnya, karena mereka mempunyai perilaku tanggap bencana dan mampu bertindak untuk menyelamatkan nyawa dan harta benda yang dianggap perlu, tanpa menunggu peringatan dan perintah dari pemerintah terlebih dahulu. Hal tersebut sesuai dengan pendapat Mirza dalam penelitiannya mengungkapkan bahwa "Perlu adanya upaya konkret dalam memahami dan mengantisipasi kondisi alam secara terpadu. Pendidikan merupakan sarana yang efektif dengan memasukkan materi pelajaran tentang bencana alam terutama di jenjang sekolah dasar yang berada di daerah rawan bencana" (Desfandi, 2014).

\section{METODE}

Penelitian ini dilaksanakan bulan Januari sampai dengan Mei 2020 di SDN Ngepanrejo Kecamatan Bandongan Kabupaten Magelang dengan menggunakan rancangan penelitian deskriptif kualitatif. Penelitian deskriptif merupakan penelitian untuk mendeskripsikan atau memberikan gejala-gejala, fakta-fakta, atau kejadiankejadian secara sistematis dan akurat mengenai sifat-sifat populasi atau daerah tertentu (Sugiyono, 2017). Selaras dengan pendapat Arikunto (2016) yang mengungkapkan bahwa penelitian deskriptif merupakan penelitian yang bermaksud 
untuk menggambarkan atau menerangkan gejala. Jadi, peneliti mengamati subjek dalam lingkungannya, berinteraksi, dan menafsirkan pendapat subjek tentang dunia sekitar.

Metode penelitian ini menggunakan metode kualitatif yang merupakan suatu strategi inquiry dengan menekankan pencarian makna, pengertian, konsep, karakteristik, gejala, simbol, maupun deskripsi tentang suatu fenomena; fokus dan multimetode, bersifat alami dan holistik; mengutamakan kualitas, menggunakan beberapa cara, serta disajikan secara naratif Yusuf (2015). Penelitian ini berupaya untuk mendapatkan informasi-informasi yang jelas serta lengkap yang berhubungan dengan manajemen kurikulum SD dalam peningkatan kesiapsiagaan bencana di daerah berpotensi bencana.

Uji keabsahan data menggunakan triangulasi sumber. Teknik analisis data yang dilakukan peneliti menggunakan model Miles dan Huberman, yaitu pengumpulan data, reduksi data, penyajian data, dan penarikan kesimpulan. Analisis data dilakukan secara interaktif dan berlangsung secara terus-menerus sampai tuntas hingga datanya jenuh.

\section{Hasil Penelitian}

\section{HASIL DAN PEMBAHASAN}

Desain Kurikulum sebagaimana dikemukakan Kepala Sekolah melalui wawancara Ibu Sakdiyah, berkaitan implementasi manajemen kurikulum SD dalam peningkatan kesiapsiagaan bencana bahwa "Pengembangan kurikulum sesuai dengan ketentuan yang berlaku yakni mengacu pada kesiapsiagaan bencana karena lingkungannya berada di lereng gunung, maka kurikulum juga memfokuskan pada siaga bencana (SPAB) yang dilaksanakan 70 mulai tahun 2017. Bencana alam yang dapat terjadi itu banjir atau tanah longsor, angin puting beliung, kebakaran.Mulai bulan April 2020 penanganan bencana dialihkan ke bencana non-alam (Covid-19)."

Konsep pengembangan dan penyusunan struktur kurikulum dan isi program yang digunakan sekolah sesuai dengan kurikulum yang berlaku dan mengacu pada kesiapsiagaan bencana karena kondisi geografis sekolah berada di daerah lereng Gunung Merbabu yang rawan bencana. Program Satuan Pendidikan Aman Bencana (SPAB) yang dimulai tahun 2017, telah menerapkan program edukasi penanganan bencana alam. Berdasarkan hasil observasi dan dokumentasi, kurikulum di SDN Ngepanrejo telah dirancang secara sistematis, jelas dan lengkap dalam bentuk tertulis dengan mengacu pada kurikulum yang berlaku.

Pernyataan tersebut diperkuat dengan hasil wawancara guru yaitu Bapak Musa, menyatakan bahwa "Semua pihak sekolah mengetahui perumusan dan penyusunan visi, misi, dan tujuan sekolah, juga sudah mengacu pada aspek-aspek Permendikbud selanjutnya disusun sesuai analisis kebutuhan, standar, dan kompetensi yang diharapkan". Disimpulkan bahwa visi, misi dan tujuan sekolah disusun secara jelas, relevan dan tertulis dengan rapi serta mengacu pada kesiapsiagaan bencana dengan menyesuaikan keadaan sekolah untuk mencapai apa yang diharapkan.

Hasil observasi, dokumentasi dan wawancara, penyusunan kalender pendidikan yang dibuat oleh pihak sekolah, telah disesuaikan dengan kondisi sekolah. Ibu Sakdiyah, menyatakan bahwa "Kaldik mengacu Dinas Pendidikan Kabupaten Magelang. Pelatihan kesiapsiagaan bencana dilaksanakan selama 2 hari bersama BPBD atau Basarnas mulai tahun 2017, 2018 dan 2019".

Pelaksanaan evaluasi kurikulum telah dilakukan secara menyeluruh, isi dan hasilnya untuk mengetahui kelebihan dan kekurangan dalam setiap bagian agar bisa diperbaiki dan dikembangkan, bahkan jika ada yang belum terlaksana bisa diprogramkan kembali pada tahun berikutnya. Hal ini sesuai dengan langkah-langkah proses evaluasi kurikulum menurut Hamalik (2013), mengevaluasi kebutuhan dan 
feasibility, evaluasi masukan, evaluasi proses, dan evaluasi produk atau dikenal dengan Context, Input, Process, and Product (CIPP).

Berdasarkan paparan di atas disimpulkan bahwa desain pengembangan kurikulum serta isi program termasuk visi, misi, tujuan sekolah, dan kalender pendidikan dirancang secara jelas, relevan, sistematis, dapat diketahui banyak orang dengan mengacu pada kurikulum yang berlaku serta terdapat program kesiapsiagaan bencana Satuan Pendidikan Aman Bencana (SPAB).

Hasil penyebaran angket terhadap 30 subjek melalui google form untuk mengetahui manajemen kurikulum dalam kesiapsiagaan bencana yang dilakukan oleh kepala sekolah dan para guru diukur dengan menggunakan skala Likert dengan butir angket berjumlah 30 item pernyataan dengan rentang skor 1-4. Berdasarkan analisis deskriptif yang diolah dengan menggunakan bantuan dari program atau software Excel dapat diketahui bahwa jumlah 2804 , nilai tertinggi 111 , nilai terendah 68 , nilai rata-rata 93,46 , modus 92, median 94, standar deviasi 8,4. Berikut ini tabel yang dibuat dari analisis deskriptifnya.

Tabel 1 Distribusi Nilai Manajemen Kurikulum dalam Kesiapsiagaan Bencana

\begin{tabular}{ccc}
\hline Interval & Frekuensi & Persentase (\%) \\
\hline $68-74$ & 1 & 3 \\
$75-81$ & 2 & 7 \\
$82-88$ & 3 & 10 \\
$89-95$ & 13 & 43 \\
$96-102$ & 8 & 27 \\
$103-109$ & 2 & 7 \\
$110-116$ & 1 & 3 \\
\hline
\end{tabular}

Maka diperoleh skor ideal maksimal adalah 4 × $30=120$ dan skala minimum ideal adalah $1 \times 30=30$.

$$
\begin{aligned}
\mathrm{Mi} & =1 / 2(\text { nilai tertinggi }+ \text { nilai terendah }) \\
& =1 / 2(111+68)=89,588 \\
\mathrm{SDi} & =1 / 6(\text { nilai tertinggi }- \text { nilai terendah }) \\
& =1 / 6(111-68)=7,16 \text { dibulatkan menjadi } 7
\end{aligned}
$$

Batasan-batasan kategori manajemen kurikulum dalam kesiapsiagaan bencana:

Tidak Baik $=\mathrm{X}>\mathrm{Mi}-1 \mathrm{SDi}$

$$
=X>89,5-(1 * 7)=X<82,5
$$

Kurang Baik $=\mathrm{Mi}>\mathrm{X} \geq \mathrm{Mi}-1 \mathrm{SDi}=89,5>\mathrm{X} \geq 89,5-\left(1^{*} 7\right)=82,5-89,5$

Baik $\quad=\mathrm{Mi}+1 \mathrm{SDi}>\mathrm{X} \geq \mathrm{Mi}=89,5+\left(1^{*} 7\right)>\mathrm{X} \geq 89,5=89,5-96,5$

Sangat Baik $=X \geq M i+S D i=X \geq 89,5+7=X \geq 96,5$

Berdasarkan kategori tersebut, maka dapat dibuat tabel distribusi frekuensi kategori manajemen kurikulum dalam kesiapsiagaan bencana, tabel tersebut dibuat seperti tabel dari Skala Likert sebagai berikut.

Tabel 2. Distribusi Kategori Manajemen Kurikulum dalam Kesiapsiagaan Bencana

\begin{tabular}{cccc}
\hline Kategori & Interval & Frekuensi & Persentase (\%) \\
\hline Sangat Baik & $X>96,5$ & 10 & 33 \\
Baik & $89,5>96,5$ & 11 & 37 \\
Kurang Baik & $82,5>82,5$ & 6 & 20 \\
Tidak Baik & $X<82,5$ & 3 & 10 \\
\hline & Jumlah & 30 & 100 \\
\hline
\end{tabular}


Data tersebut menunjukkan bahwa manajemen kurikulum dalam kesiapsiagaan bencana di SD Negeri Ngepanrejo masuk dalam kategori baik.

\section{Pembahasan}

Hasil analisis deskriptif manajemen, perencanaan, konsep pengembangan, penyusunan struktur kurikulum, isi program, termasuk visi, misi dan tujuan sekolah, serta perangkat pembelajaran yang digunakan sudah disesuaikan dengan kurikulum dan mengacu pada kesiapsiagaan bencana Satuan Pendidikan Aman Bencana (SPAB). Kurikulum tersebut belum tercantum secara khusus, tetapi materi kesiapsiagaan telah masuk dalam ranah Lingkungan Hidup. Kondisi tersebut diperlukan adanya perubahan dan pengembangan kurikulum yang sesuai dengan perkembangan Iptek serta perkembangan SD Negeri Ngepanrejo yang ikut merealisasikan penanganan Covid-19 sesuai dengan Surat Edaran Mendikbud Nomor 3 Tahun 2020 tentang Pencegahan Covid-19 pada Satuan Pendidikan.

Konsep penyusunan kurikulum SD Negeri Ngepanrejo menggunakan kurikulum 2013 tematik dengan mengintegrasikan program SPAB dan Adiwiyata. Pola perencanaan dan pengembangan kurikulum tersebut, guru diberi tugas menyusun prota, promes, silabus, RPP dan isi program dapat dimodifikasi sesuai kebutuan dan tujuan yang ingin dicapai. RPP disusun berdasarkan Permendikbud No. 22 Tahun 2016 dan Permendikbud No. 37 Tahun 2018 yang berkaitan dengan kesiapsiagaan bencana.

Perencanaan dan pengembangan kurikulum melibatkan banyak pihak stakeholder seperti guru kelas, guru mata pelajaran, Komite Sekolah dan Instansi UPT Disdikbud Kecamatan Bandongan Kabupaten Magelang. Hal ini sesuai dengan pendapat Hamalik (2013), bahwa salah satu prinsip perencanaan kurikulum adalah melibatkan banyak pihak, antara lain kelompok guru mata pelajaran, kepala sekolah, pemerhati pendidikan, orang tua, stakeholder, dan pihak-pihak lain yang terkait. Masukan dari banyak pihak untuk kemajuan sekolah akan meningkatkan perencanaan kurikulum menghasilkan program sekolah yang lebih baik.

Berdasarkan uraian diatas, disimpulkan bahwa SD Negeri Ngepanrejo dalam perencanaan baik dari segi desain kurikulum, perangkat pembelajaran, penilaian dan pengorganisasian sudah berpedoman pada KTSP yang berlaku dan memuat program Satuan Pendidikan Aman Bencana (SPAB), serta melibatkan banyak pihak. Tim peneliti melihat model pendidikan bencana di SD Negeri Ngepanrejo telah dipahami secara menyeluruh baik dari aspek kognitif maupun manajerial. Mereka menyadari bahwa kurikulum pendidikan bencana merupakan inti dalam pembelajaran generasi tanggap bencana, sehingga hal tersebut tidak terabaikan dalam implementasi Satuan Pendidikan Aman Bencana.

Pembahasan tersebut sesuai hasil penelitian manajemen kurikulum oleh Haryaningrum dkk.(2017) menunjukkan bahwa perencanaan kurikulum dilakukan secara intensif dan mendalam oleh banyak pihak yaitu yayasan, Kepala Sekolah, tenaga pendidik, tenaga kependidikan, dan masukan dari orang tua murid, yang dijiwai oleh visi, misi sekolah. Demikian pula pendapat Rusman (2012) bahwa fungsi perencanaan sebagai pedoman pelaksanaan dan pengendalian, menghindari pemborosan sumber daya, sebagai alat pengembangan mutu, dan memenuhi akuntabilitas lembaga sekolah.

\section{SIMPULAN}

Simpulan hasil penelitian menyatakan bahwa SD Negeri Ngepanrejo Kecamatan Bandongan Kabupaten Magelang dalam perencanaan kurikulumnya baik dari segi desain, perangkat pembelajaran, program penilaian dan pengorganisasian strukturalnya sudah berpedoman pada KTSP yang berlaku, memuat program Satuan Pendidikan Aman Bencana (SPAB) terorganisir dengan baik. Pelaksanaan kurikulum telah memenuhi ketentuan prinsip dan pedoman pelaksanaan sesuai Permendikbud 
No. 20 Tahun 2003 dan SPAB. Evaluasi kurikulum menggunakan model CIPP dan mampu memberikan dampak positif untuk mengembangkan kurikulum lebih baik lagi dan menciptakan generasi siaga terhadap bencana.

\section{DAFTAR PUSTAKA}

Arikunto, S. (2016). Manajemen Penelitian. Jakarta: Rineka Cipta.

BNPB (2017) „Latihan Kesiapsiagaan Bencana", Jakarta.page 145.

Defyanti, V. (2014). „Pelaksanaan Manajemen Kurikulum 2013 Pada Tingkat Sekolah Dasar di Kecamatan Tanjung Emas", Jurnal al-Fikrah, Vol. II, N, pp. 177-185.

Desfandi, M. (2014) „Urgensi Kurikulum Pendidikan Kebencanaan Berbasis Kearifan Lokal di Indonesia [The urgency of disaster education curriculum based on local wisdom in Indonesia\}", Sosio Didaktika Sosial Science Education Journal, 1(2).

Febriana, Sugiyanto, D. dan Abubakar, Y. (2015) „Kesiapsiagaan Masyarakat Desa Siaga Bencana Dalam Menghadapi Gempa Bumi Di Kecamatan Meuraxa Kota Banda Aceh", Ilmu Kebencanaan (JIKA) Jurnal Pascasarjana Univeritas Syiah kuala, 2(3), pp. 41-49.

Hamalik, Oemar. (2013). Dasar-Dasar Pengembangan Kurikulum. Bandung: PT. Remaja Rosdakarya.

Haryaningrum, R., Muhdi and Retnaingdyastuti (2017) „Manajemen Kurikulum Sekolah Dasar Islam Terpadu Insan Mulia Kajen Kabupaten Pekalongan", Jurnal Upgris, pp. 129-141.

Husna, C . (2011) „Faktor-faktor yang mempengaruhi Kesiapsiagaan Bencana di RSUDZA BANDA ACEH Influencing Factors on Disaster Preparedness in RSUDZA Banda Aceh". Available at: http://www.jurnal.unsyiah.ac.id/INJ/article/viewFile/1578/1459.

Pitang, Y., Irman, O. and Nelista, Y. (2019) „The Effect of Trainining on Preparedness Disaster on the Preparadness of Elementary School Children in Overcoming the Disaster of Volcano Eruption of Mount Egon in Lere 117 Catholic Elementary School" , NurseLine Journal, 4(2), pp. 139-145.

Sugiyono. (2017). Metode Penelitian Pendidikan (Pendekatan Kuantitatif, Kualitatif, dan $R \& D$ ). Bandung: CV. Alfabeta. (2018). Metode Penelitian Kualitatif. Bandung: CV Alfabeta.

Yusuf, M. (2015). Metode Penelitian Kuantitatif, Kualitatif \& Penelitian Gabungan. Jakarta: Prenadamedia Group. 